\title{
前立腺肥大症に伴う排尿障害を合併した 高血圧症患者に対するドキサゾシンの効果
}

\author{
稲 葉 宗 通* 丸 野 世志子* 小瀬 川 至* \\ 片 山茂 裕*
}

目的

$\alpha_{1}$ 遮断薬であるドキサゾシンは、1日1回投 与で高血圧症に対する有用性が認められてい る。また同時に、海外での臨床試験により前 立腺肥大(B P H ) に伴う排尿障害に対してそ の有用性が確認されている")。そこで今回、 BPHに伴う排尿障害を合併した高血圧症患者 に対するドキサソシシンの有用性について、エ ナラプリルを対照薬として比較検討した.

対象および方法

対象は、BPHに伴う排尿障害を合併した高 血圧症患者で以下の基準を満たす症例とした。

1）80 歳未満の男性で、2) 観察期に収縮 期血圧 $140 \mathrm{~mm} \mathrm{Hg}$ 以上または拡張期血圧 $90 \mathrm{~mm} \mathrm{Hg}$ 以上の高血圧症を有し、3) WHO/ISHの高血圧重症度分類で I 期または II 期。さらに 4) 国際前立腺症状スコア (international prostate symptom score : I-PSS）にて中等症以上 $(8$ 点〜)で、自覚症状 にて排尿障害の認められる男性患者を対象と した。なお、起立性低血圧、神経因性膀胱、

1 年以内の BPHの手術既往のある患者、前立 腺癌等の排尿に影響を及ぼすと思われる合併 症を有する患者あるいは現在治療中の患者は 除外した。

調査方法は、2 週間の観察期の後、封筒法に てドキサゾシンあるいはエナラプリルを割り 付け、ドキサゾシンは $0.5 \mathrm{mg}$ 、エナラプリル

* 埼玉医科大学第四内科

干 350-0495 埼玉県入間郡毛吕山町毛呂本郷 38
は $5 \mathrm{mg}$ から 1 日 1 回投与を開始した。また、 調查期間中は原則として併用薬は禁止した。 観察期と治療期 12 週間後に外来における随時 血圧と脈拍の測定および排尿障害に起因する 自覚症状のアンケート調査を行い、前後で比 較検討した。

I-PSSは、1994 年のWHO前立腺肥大症 取り扱い委員会報告書の前立腺症状とQuality of Life（QOL）の評価法に基づき、排尿に関 する 7 つ質問からなり、各質問に対し 0 〜 5 点のスコア式で $0 \sim 35$ 点の合計值により 重症度を分類した。質問内容は、1、残尿感、 2 、頻尿、 3 、尿線の中断、 4 、尿意切迫感、 5 、尿線の勢いの低下、6、排尿時の腹圧、 7、夜間排尿回数からなり、さらにQOLに ついての質問は「うれしい」から「つらい」 まで $0 \sim 6$ 点のスコアからなる。

結 果

症例はドキサゾシン投与群（D群）5例 (平 均年齢 $71.6 \pm 2.7$ 歳 $($ mean \pm S. E ) 、最終投与 量は全例 $1 \mathrm{mg} /$ 日)、エナラプリル群 ( $\mathrm{E}$ 群) 5 例 $(68.2 \pm 3.6$ 墄、全例 $5 \mathrm{mg} /$ 日). 血圧はD 群で観察期 $149.2 \pm 15.6 / 77.0 \pm 10.0 \mathrm{mmHg}$ から治療 12 週後には $134.4 \pm 8.4 / 75.6 \pm$ $9.5 \mathrm{mmHg}$ 、またE群においても $153.2 \pm$ $11.2 / 75.0 \pm 7.3 \mathrm{~mm} \mathrm{Hg}$ 的 $126.4 \pm$ $13.7 / 68.0 \pm 3.2 \mathrm{~mm} \mathrm{Hg}$ へ共に有意に低下し た $(\mathrm{p}<0.01)$. 脈拍は各群とも治療前後、群 間に差はみられなかった。排尿障害について のアンケートにおいて、I-PSS総得点はD 群で $14.8 \pm 5.6$ 点から $9.4 \pm 1.7$ 点と有意に改善し たが、E群では $14.6 \pm 9.0$ 点から $17.5 \pm 9.7$ 点 


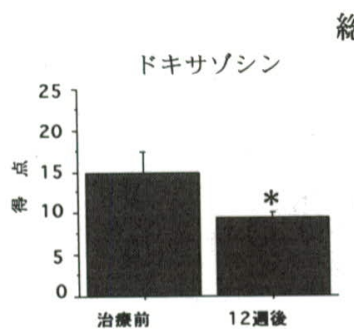

総得点
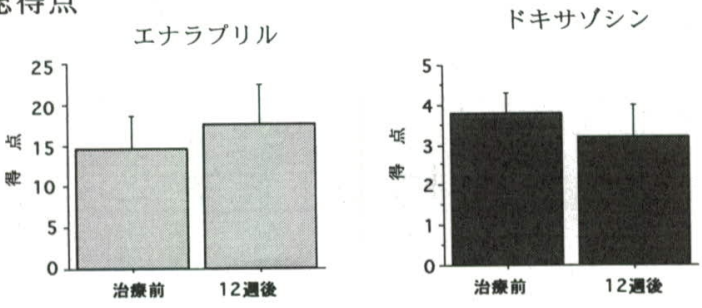

Q O L

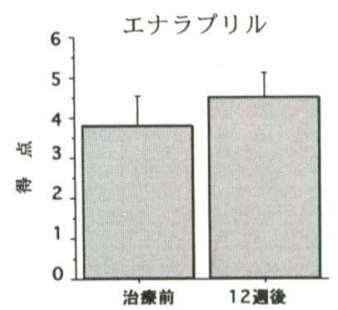

Fig 1. ドキサソ゚シンとエナラプリル投与による国際前立腺症状スコアの変化 総得点（左）及び Q O L (右) を示す。*: p < $0.05 \mathrm{vs}$ 治療前

へ上昇傾向を示した。 QOLスコアにおいても $\mathrm{D}$ 群では $3.8 \pm 1.1$ 点から $3.2 \pm 1.8$ 点へ改善傾 向を示したが、 $\mathrm{E}$ 群では $3.8 \pm 1.6$ 点から 4.5 \pm 1.3 点へ増悪傾向を示した (Fig 1$)$ ）次に、 各質問項目毎にスコアの変化をみると、1、 残尿感についての質問では、D 群において投 与前の 1.8 から投与後 0.8 へ有意に改善し、 $\mathrm{E}$ 群と比しても有意差を認めた（ $\mathrm{E}$ 群 : 2.8 から $3.0 ） 。 2$ 、頻尿に関しては、D 群で 2.0 から 1.2 へ減少傾向を示したが、 $\mathrm{E}$ 群では変化を認 めかっかた。3、尿線の中断では、 D 群、 $\mathrm{E}$ 群ともに変わらなかった。4、尿意切迫感に ついては、D 群で 2.2 から1.2へ改善傾向を示 したのに対し、 $\mathrm{E}$ 群では 1.8 と変化を認めなか った。 5 、尿線の勢いの低下では、D群でや や改善を認めたが、 $\mathrm{E}$ 群は変化がタられなっ かった。6、排尿時の腹圧については、 D 群 で1.8から0.8へ有意に改善した $(\mathrm{p}<0.05)$ 。 一方、 $\mathrm{E}$ 群では 0.2 から 2.2 へ有意に増加した。 7 、夜間排尿回数についても、 $\mathrm{D}$ 群では 3.2 か ら2.2へ有意 $(\mathrm{p}<0.05)$ に改善したが、 $\mathrm{E}$ 群では2.0から2.8へ増加傾向を示した。

\section{考 案}

一般的に、 $\alpha_{1}$ 遮断薬は降圧薬としての 夕な らず、B P H の排尿障害に対しても有用であ ることが知られている。これまで降圧薬とし て有用性の認められている $\alpha_{1}$ 遮断薬であるド キサゾシンに関しては、Gillenw aterら ${ }^{11} に$ より、B P Hに対する有效性が報告されてい
る。その中で、最大尿流量率はドキザソシン $4 \mathrm{mg} /$ 日以上で有意な改善を認め、平均尿流量 率は $8 \mathrm{mg}$ 以上で有意差を認めている。また、 症状スコアにおいても $4 \mathrm{mg}$ 以上で有効であっ たと報告されている。しかしながら、今回の 検討では、全例 $1 \mathrm{mg}$ の投与量であり、少量の ドキサソシシン投与でBPHの症状の改善ばかり でなくQOLの改善傾向を認めた。また、今回 の症例の平均年齢は 7 1歳と高龄であったが、 ドキサソシン $1 \mathrm{mg}$ の投与で重大な副作用もな く、B P Hに伴う症状の改善を夕たことは、 ドキサゾシンの少量投与は、BPHを伴いやす い高齢者の高血圧症患者に、特に有用性が高 いと考えられる.

また、今回対照薬として、降圧薬の中で B P H に影響しないアンジオテンシン変換酵素 阻害薬であるエナラプリルを用いた。エナラ プリル群ではスコアが増加する項目もあった が、経時的変化とも考元られる。さらに経過 観察が必要と考えられる。

\section{文 献}

1). Gillenwater J Y, et al . Doxazosin for The Treatment of Benign Prostatic Hyperplasia in Patients with Mild to Moderate Essential Hypertension : A Double-Blind, Placebo-Controlled, Dose-Response Multicenter Study.

J Urol 154: 110-115, 1995 